\title{
PERFORMANCE TESTS AND DESIGN OUTPUTS OF DIESEL FORKLIFTS
}

\author{
Halil. Çetin ${ }^{1 *}$ \\ *l Burdur Mehmet Akif Ersoy University of Engineering and Architecture Faculty of Mechanical Engineering \\ Department of Burdur, 15000 Turkey
}

\section{*Corresponding Author: -}

\begin{abstract}
: -
In order to improve the characteristics of the $3000 \mathrm{~kg}$ capacity diesel forklifts we are working on, KFD30 Forklift was developed with the aim of increasing performance. After the design and denge assembly stages of this prototype model, stability tests and performance tests were performed in accordance with TSE ISO Standards. In order to find the maximum performance outputs of the diesel forklift we developed, the test results were taken into consideration and adaptations were made on our prototype model. Surface slopes and velocities that our model could work with and without load were determined. The center of gravity of our model was found to ensure that the load center does not go outside the balance triangle during operation. It is very important that the test results also confirm our original values.
\end{abstract}

Keywords: Performance outputs, balance triangle, stability, load center

\section{(ㄷ) (\$) (1)}




\section{INTRODUCTION}

A literature review was performed and similar studies were evaluated[1,2,3], (4,5], Stability tests were performed on $2 \%$ $4 \%$ 6\% 18\% slope surfaces in accordance with ISO22915 standards[6]. In our study, performance tests were performed on $25 \%, 28 \%, 30 \%, 32 \%$ and $31.5 \%$ slope surfaces in order to see the limit points that our prototype model can reach on these different sloped surfaces and to make changes on the design considering the results. It was observed that our prototype model was stable in the inclination direction outputs. On these slopes, it was observed that the slopes were unstable. $760 \mathrm{~mm}$ printed steel platform was used as test platform. In addition, to determine the tipping point of our model loaded and unloaded, the tipping test was performed. In order to determine the maximum speed of our model on inclined flat ground, speed tests were performed on a selected special road with and without load. Fig. 1 shows our prototype forklift model.

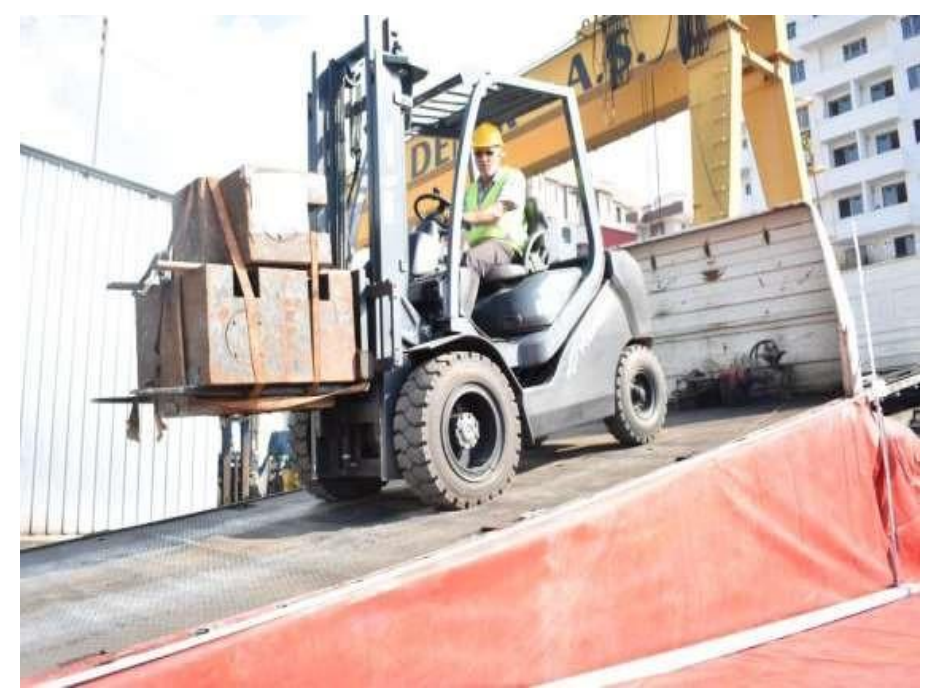

Figure 1. Performance tests of our prototype model forklift.

\section{Performance tests and examination}

TSE ISO 22915 standartlarına göre stabilite testlerine göre sınır noktalarını yakalamak için performans testleri yapılmıştır. $\mathrm{Bu}$ amaçla, performans testlerini ikiye bölmek mümkündür. Bunlar eğimli yüzeylerde statik ve dinamik testler ile, düz yüzeylerde test olarak sinıflandırılabilir.

\subsection{Tests on sloping surfaces:}

It is possible to carry out these tests according to various inclination angles. A part of the tests in our model was made on the printed steel platform which is $760 \times 220 \mathrm{~cm} 2$. These tests are, respectively, $18 \%, 25 \%, 28 \%, 30 \%, 32 \%$ and $30 \%$ and $31.5 \%$ tilting tests performed on the slope surface[7,8,9].

\subsubsection{8\% sloping surface}

KFD30 model with a length of $760 \mathrm{~mm}$ on this test, the following mathematical model has been utilized. Fig. 2 shows the platform sizes.

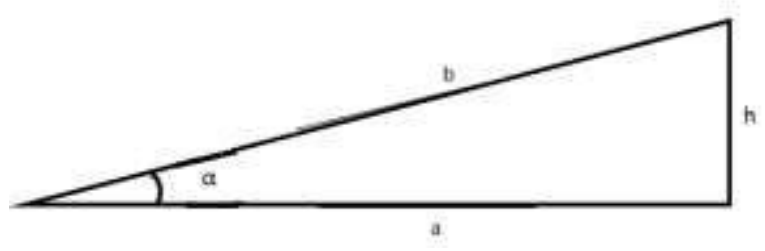

Figure 2. Platforms and sizes used

$\alpha$ To find the angle of inclination, $\operatorname{tg} \alpha=\frac{h}{a}$

$$
\operatorname{tg} \alpha=\frac{18}{100}
$$

From this equation, it is written on an inclined surface of $18 \%$ to find the $\alpha$ angle. Here, $\alpha=10^{0} .2$ is found.

$$
\text { platform height: } \operatorname{Cos} \alpha=\frac{h}{760}
$$


The phrase,

The test was repeated 5 times, with $3000 \mathrm{~kg}$ loaded and unloaded. Our prototype model was successfully climbed to the inclined surface of $18 \%$.

\subsubsection{5\% Curved surface}

Working speed of our prototype model on 25\% inclined surface, From ISO 22915 standards, the relationship between forklift speed and surface slope was expressed by equation (3) below.

$$
15+1.4 \mathrm{v}=25^{0}
$$

This expression is $v=7.4 \mathrm{~km} / \mathrm{h}$. With this speed, our model should climb to the platform. It was observed that our model successfully loaded onto this platform with this speed.

\subsection{3. $28 \%, 30 \%, 32 \%$ Inclined surfaces:}

These three different curved surfaces were examined together. Below, the inclined surfaces 16,17,18 are shown in fig.3
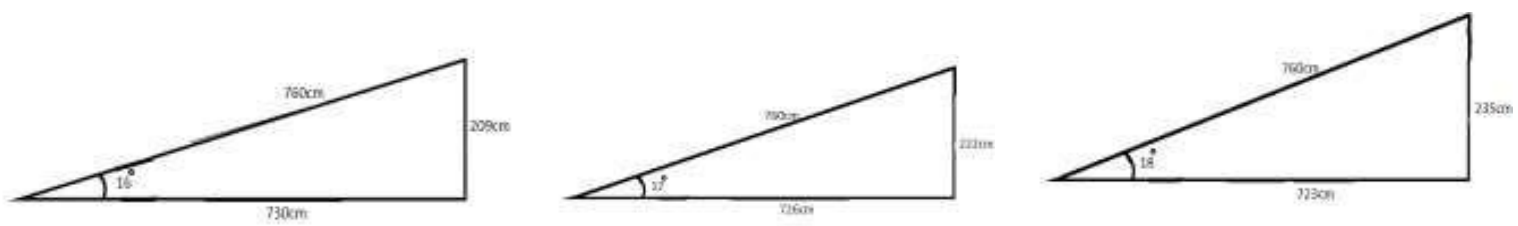

Figure 3. Platform sizes are seen on $28 \%, 30 \%, 32 \%$ slope surfaces respectively. Seen.

The following results were obtained respectively on these inclined surfaces. $28 \%$ inclined surface, $3000 \mathrm{~kg}$ load to the platform forward output stable, rear output unstable, $30 \%$ inclined surface, with $3000 \mathrm{~kg}$ load, platform forward output stable, rearward output unstable. On an inclined surface of $32 \%$, with a load of $3000 \mathrm{~kg}$, it was observed that the output to the platform was stable, the rear outputs were unstable[10,11].

\subsubsection{5\% Tilting test on sloping surface}

On this inclined surface, our truck is positioned below the ground and one edge of the triangle with the center of gravity parallel to the floor. For this purpose, the distance of the lateral edge of the triangle between the front wheel axle center and the axle centers of the rear wheels to the ground is taken as $460 \mathrm{~mm}$. At the end of the platform output of our model, as shown below, it was observed that it dived stably with $3000 \mathrm{~kg}$ load. Fig. 4 below shows the distance of the balance triangle from the ground.

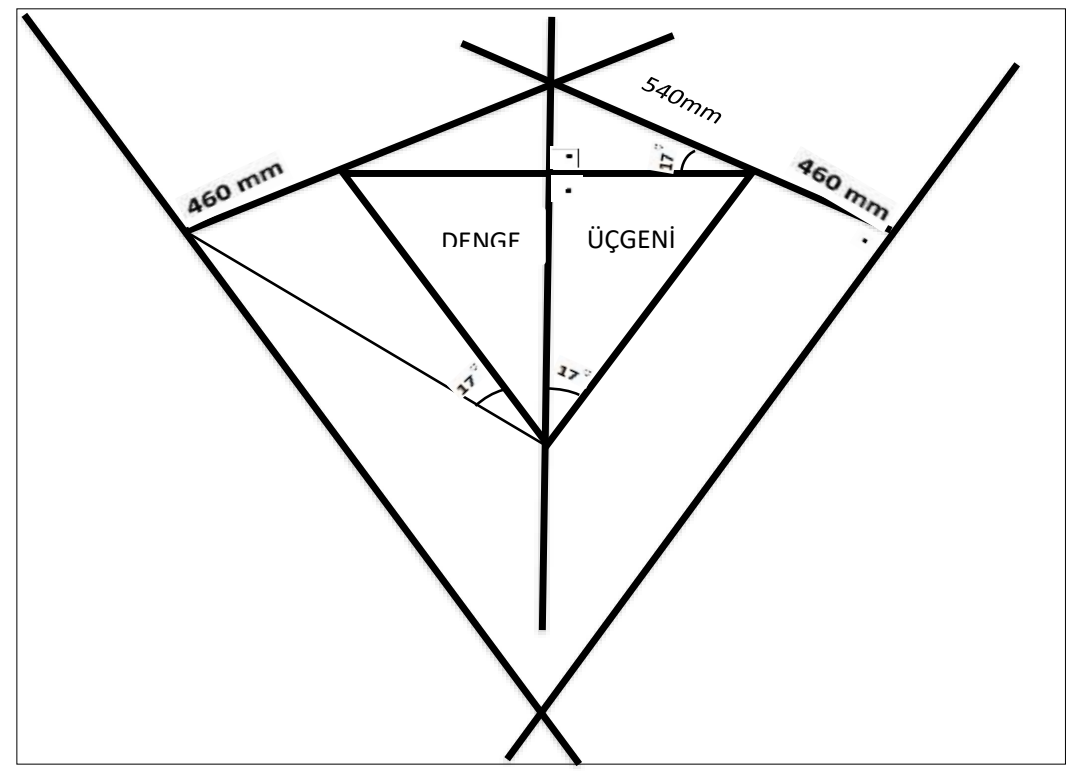

Figure 4. The distance from the balance triangle is seen.

Our model climbed to the platform at $11.4 \mathrm{~km} / \mathrm{h}$ and was able to stand steadily in the position shown above. This position on a slope of $31^{0}, 5 \%$ is called the tipping point. Düz zeminde yapılma zorunluluğu olan, modelimizin hız performans deneyleri yapıldı.

\subsection{Tests on flat surfaces:}

With our prototype model, speed tests were performed on flat ground. 


\subsubsection{Speed tests}

Speed tests with the KFD30 model were performed with 3000kg load and no load. Below is the speed track in Fig. 5.

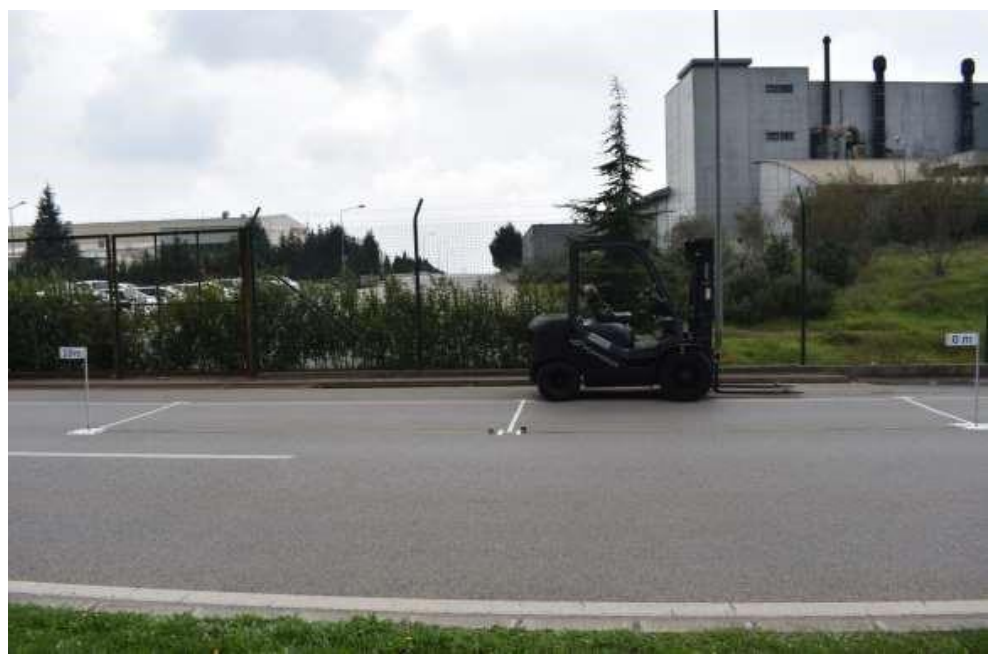

Figure 5. Speed test track

$10 \mathrm{~m}$ long path was selected for the speed test. The transition time of our prototype model was determined by the stopwatch. Speed = According to the road / time formula, the speed of our model was determined as $19.5 \mathrm{~km} / \mathrm{h}$, and $20 \mathrm{~km} / \mathrm{h}$, with without load of $3000 \mathrm{~kg}$.

\section{Conclusions}

After the standard test we have done with the diesel forklift model with a capacity of $3000 \mathrm{~kg}$, we have successfully completed the stability tests shown in the performance limits of our model. These test results also showed at which road slopes and at what speed our prototype model can be used with and without load. During the operation of our model, the limit values in our performance tests were determined in order to keep the load center within the balance triangle. With our forklift model, the required speeds were determined according to the slope of the ground in order to operate safely. Then, considering the performance outputs, necessary design and construction changes were made in our model. At the end of these studies, the necessary changes were made on our prototo type model and the production phase was started.

\section{Acknowledgment}

In this study, the above tests, the partner of the project, Teknolift Ltd.Şti. was on the premises. Thank you to the company.

\section{Referanslar}

[1].The Finite Element Analysis and Geometry Improvements of Some Structural Parts of a Diesel Forklift Truck. Ömer Yavuz Bozkurt, İhsan Cihan Dai, Özkan Özbek Mechanical Engineering Department, Gaziantep University, Gaziantep, Turkey. June 2017. Gaziantep, Turkey : Periodicals of Engineering and Natural Sciences, June 2017, Cilt Vol.5, No.2, pp. 202 209. ISSN 2303-4521.

[2].Parametrical analysis of the dynamic behaviour of a forklift truck andconditions of its tip-over. Jérôme REBELLE,Institut National de Recherche et de Sécurité, Avenue de Bourgogne, 54501 Vandoeuvre -LèsNancy Cedex,France. 2007. Lyon,France : 14th International Conference Vehicle Dynamics, 2007.

[3].Rebelle, J., Mistrot, P., Poirot, R., 2007. Development and validation of a numerical model for predicting forklift truck tip -over. Paper submitted to Vehicle System Dynamics the 2 nd April 2007.

[4].HSE report. 2006. Fork lift truck validation and trials. Research report 456. Available at http://www.hse.gov.uk/research/rrhtm/rr456.htm

[5].Comparison of visibility measurement techniques for forklift truck design factors. ChinBongChoi,PeomPark,Young-HoKim,M.Susan Hallbeck,Myung-ChulJung,Industrial and Information Systems Engineering, Ajou University, Suwon 443-749, South Korea,R\&D Center, Doosan Infracore, Incheon 401-020, South Korea. 23 May 2008. Suwon : Elsevier Applied Ergonomics, 23 May 2008, Cilt Volume 40, Issue 2, March 2009, Pages 280-285. https://doi.org/10.1016/j.apergo.2008.04.012.

[6].“Industrial trucks — Verification of stability — Part 1: General”, TS-ISO 22915,: Part 1, Edition : 2,Number of pages : 8 (2016).

[7].Allotta, B., Costanzi, R., Monni, N., Natalini, M., Pugi, L., \& Ridolfi, A. (2014, September). Fast prototyping of a scaled AGV for the testing of stability control for industrial vehicles. In Education and Research Conference (EDERC), 2014 6th European Embedded Design in (pp. 202-206). IEEE.

[8].Sutru, N., Boiangiu, G., \& Popescu, S. (2012). Contributions to theoretical and experimental study of the dynamic stability of the forklift trucks. In Journal of EcoAgriTourism (Vol. 8, No. 2, pp. 150-156). Transilvania University Press 
[9].Simion, P., Sutru, N., \& Carol, C. (2012). Contributions to the theoretical and experimental study of the dynamic stability of the forklift trucks. Journal of Engineering Studies and Research, 18(3).

[10]. Complex CAD surface shape design using semantic features. Fengbei Cheng, Zhenyu Liu, Guifang Duan, Chan Qiu, Bing Yi and Jianrong TanState Key Laboratory of CAD\&CG, Zhejiang University, Hangzhou 310027, China.,. 2014. Hangzhou : Journal of Mechanical Science and Technology, 2014, Cilt 28 (7) (2014) $2715 ~ 2722$. DOI 10.1007/s12206-014-0628-y.

[11]. Research on all-wheel steering control strategy for the three-wheel forklift. Zuxun Xiao, Benxian Xiao ,School of Electrical Engineering and Automation, Hefei University of Technology, Hefei, 230009, China. 2016. Hefei, 230009, China. : Springer,Journal of Mechanical Science and Technology, 2016. 10.1007/s12206-016-0943-6. 